\title{
Characteristics that make the Fallopia genus (Polygonaceae) highly invasive
}

\author{
Justyna Soltysiak, Teresa Brej \\ Department of Botany and Plant Ecology, Wrocław University of Environmental and Life Sciences, \\ pl. Grunwaldzki 24a, 50-363 Wrocław, Poland \\ e-mail: justyna.soltysiak@up.wroc.pl
}

\begin{abstract}
Representatives of the Fallopia genus: Fallopia japonica, Fallopia sachalinensis and Fallopia $\times$ bohemica are known as successful invaders, wide spread throughout Europe and North America. This paper focuses on the invasive Fallopia complex and presents some features (a wide ecological amplitude, high competition abilities, sexual reproduction by hybridization) responsible for the fact that all species of the Fallopia genus are aggressive and noxious invaders.
\end{abstract}

Key words: plant invasion, Fallopia japonica, Fallopia sachalinensis, Fallopia $\times$ bohemica.

\section{Introduction}

Biological invasions belong to the main problems of contemporary ecology and they are considered as a significant component of global changes, connected with human activity (Vitousek et al. 1997; Vilá et al. 2007; McKinney 2006).

The major point of the biological invasions was the discovery of America by Christopher Columbus in 1492, which has facilitated exchange of goods between new and old continent. Before this period animals and plants exchange were limited by multiple biogeographically barriers. Crossing of those borders has enabled species migration from one part of the world to another, where they may become invasive. The biological invasion processes have been increased in the first half of the 1900s, through the international tourism and transport development as well as global trade. During that time many species were introduced into new countries on purpose. For example, an invasive plants such as: Acer negundo, Robinia pseudoacacia, Quercus rubra were planted into European and Polish parks or gardens as ornamental plants (Tokarska-Guzik 2005). It has been estimated that in the world 30000 spe- cies of exotic plants have been introduced as a crop and have escaped to become established in natural ecosystems (Pimentel et al. 2007).

Recent research were dedicate to invasive species, despite that fact scientist still try to find the answer for the question: what characteristics make them invasive? (Rejmánek 1995).

The article is dedicated to the Fallopia genus, whose some species are known as successful invaders, wide spread in Europe and North America. In this paper it will be presented biological and ecological properties of the Fallopia genus, facility its large invasion success.

\section{The taxonomy of presented species}

The genus Fallopia (Polygonaceae) includes three highly invasive species: Fallopia japonica (Houtt.) Ronse Decraene var. japonica [syn.: Polygonum cuspidatum Sieb. et Zucc., Reynoutria japonica Houtt. var. japonica], Fallopia sachalinensis (F. Schmidt) Ronse Decraene [syn.: Polygonum sachalinense F. Schmidt, Reynoutria sachalinensis (F. Schmidt) Nakai] and Fallopia $\times$ bohemica (Chrtek 
et Chrtková) J. P. Bailey [syn.: Polygonum $\times$ bohemicum (Chrtek et Chrtková) P. F. Zika et A. L. Jacobson, Reynoutria $\times$ bohemica Chrtek et Chrtková] (Bailey et al. 2008).

The classification and nomenclature of presented species have been changed, because of the historical complication (Beerling et al. 1994; Bailey \& Conolly 2000). In Europe the species are recognized in two different generic names: Reynoutria and Fallopia. Bailey and Wisskirchen (2006) inform that Fallopia combinations are on the standard list of British and German flora, while Czech researchers usually use Reynoutria as a generic name. Likewise, in Polish publications exist the genus Reynoutria (Mirek et al. 2002; Tokarska-Guzik 2005). Meanwhile outside of Europe (America, Canada, and Japan) authors prefer Polygonum combinations (Bailey \& Wisskirchen 2006). In this article we follow by Bailey and Stace (1992), using the generic name Fallopia.

Fallopia japonica and Fallopia sachalinensis show a sexual reproduction by hybridization. The result of this process is to create a new hybrid - Fallopia $\times$ bohemica (Bailey 2003; Bailey et al. 2007). In addition various back-crosses of Fallopia $\times$ bohemica and its parents have been found in Graet Britain (Bailey 2003). Hybrids (well-rounded in morphology and ploidy level) is intermediate between the parental species and they are difficult to recognize (Bailey 2003). For that reason, Fallopia japonica, Fallopia sachalinensis, Fallopia $\times$ bohemica as well as all backcrosses between hybrids and parental species are referred to as Japanese Knotweed s.l. (Bailey \& Conolly 2000; Bailey et al. 2008).

\section{The range of the Fallopia genus invasion}

Fallopia japonica and Fallopia sachalinesis are native to eastern Asia. The natural range of Fallopia japonica encompasses mainly in China, Japan, North and South Korea and Taiwan (Beerling et al. 1994; Bailey 2003; Bailey et al. 2007). The native distribution of Fallopia sachalinensis is more limited, restricted to Sakhalin Island, North Japan and Korea (Sukopp \& Starfinger 1995; Bailey 2003; Bailey et al. 2008).

Both species were introduce into Europe in the $19^{\text {th }}$ century and have become the most destructive and aggressive of all alien weeds (Mandák et al. 2004). They became popular as ornamental plants and were sold by gardens and parks in various countries (Bailey 2003; Mandák et al. 2004). Fallopia japonica was also promoted as a medical plant and it has the advantage in protecting young plantation from wind or sun (Bailey \& Conolly 2000). In the meantime, Fallopia sachalinensis was recommended as a forage plant (Bailey \& Conolly 2000), as a riverbank stabilizer (Bailey \& Conolly 2000) and for decontamination of soils polluted by heavy metals (Sukopp \& Starfin- ger 1995). Today Fallopia japonica and Fallopia sachalinensis are covering areas in almost all of Europe (Berling et al. 1994). Especially, Fallopia japonica has become a widespread species. For instance, in Czech Republic in 1996-2000 the number of Fallopia genus locations has been reported to be: 1335 locations of Fallopia japonica, 381 of Fallopia $\times$ bohemica and 261 locations of Fallopia sachalinensis (Mandák et al. 2004). In Poland the total amount of Fallopia japonica, Fallopia sachalinensis and Fallopia $\times$ bohemica populations is still unknown, but in the cities we can still observe the distinct increase of their clumps. In Wrocław in 2009-2011 were noted 310 clusters of the Fallopia genus. Among them the most frequent species was Fallopia japonica, while Fallopia sachalinensis was very rare (Sołtysiak \& Brej, in prep.).

Outside Europe Fallopia japonica and Fallopia sachalinensis are recorded from North America (Seiger 1997; Barney et al. 2006), Australia and New Zealand (Beerling et al. 1994; Bailey et al. 2007; Bailey et al. 2008). The most common is Fallopia japonica. This species has been reported from $71 \%$ of the countries in the northeastern part of the United States. Its presence was noted near the Mississippi River and in the semidesert areas of Colorado and Utah (Seiger 1997; Barney et al. 2006). Isolated populations have even been found in the southern part of Alaska (Barney et al. 2006). In Canada Fallopia japoni$\mathrm{ca}$ is spreading from Ontario, Quebec and Newfoundland throughout Prince Edward Island (Barney et al. 2006).

Fallopia $\times$ bohemica is a hybrid between Fallopia japonica and Fallopia sachalinensis. It was first described in Europe in 1983, while in Asia (a native area of parental species) Fallopia $\times$ bohemica was not recognized until 1997 (Bailey 2003). Distribution of hybrid in an invasive range is broadly similar to its congeners. Fallopia $\times$ bohemica is spreading across Northern and Central Europe (Bailey \& Stace 1992; Mandák et al. 2004; Bailey \& Wisskirchen 2006; Bailey et al. 2007). The hybrid is common in North America, Canada, New Zealand and Australia (Bailey 2003; Zika \& Jacobson 2003).

\section{Ecological amplitude and habitat prefer- ence of the Japanese knotweed}

To become a successful invader a plant species must possess a wide environmental tolerance and be well suited in various conditions (Bradley et al. 2010). Undoubtedly, the success of the genus Fallopia invasion is connected with its broad ecological amplitude. They are widespread in different climate zones - from cold, into desert climates. Species of the Fallopia genus endure well heavy mountains climate, what confirm the research of Yamaguchi et al. (2000). According to Beerling (1993) Fallopia japonica rhizomes can survive even the temperatures as low as minus $42^{\circ} \mathrm{C}$. 
Japanese Knotweed is common in all kinds of habitats, especially changed by human influence. They spread along river banks, road, railways and into disturbed areas (Beerling et al. 1994; Mandák et al. 2004). Species of the Fallopia genus are frequent components of urban ecosystems, where their range increases quickly. It seems that uniquely urban conditions promote the expansion of all species.

Representatives of the Fallopia genus are able to grow in diverse soil types, with various $\mathrm{pH}$ ranges and nutrient content: from colliery soils through alluvial soils, clays and loams to mineral soils and even peats (Beerling et al. 1994). Richards et al. (2008) reported Knotweed taxa from saline habitats of The United States. Additionally, they can tolerate sulphurous soils. Adachi et al. (1996) described Fallopia japonica var. compacta (a mountain range variety of Fallopia japonica) as a dominant perennial pioneer species in the volcanic wasteland on Mt. Fuji. Fallopia japonica has also grown in soils with a high concentration of heavy metals. Nishizono et al. (1989) reported Fallopia japonica from heavy metals polluted areas of Japan. Kubota et al. (1988) has found cooper-binding proteins in root of Fallopia japonica and suggested its tolerance to heavy metals. Also the investigation in the urban conditions of two European cities: Wroclaw and Prague has shown that Fallopia japonica and Fallopia $\times$ bohemica spread on soils with higher than natural content of $\mathrm{Cd}, \mathrm{Fe}, \mathrm{Pb}$ and Zn (Sołtysiak et al. 2011). According to authors, even soils rich in heavy metals can be susceptible to invasion by the genus Fallopia.

\section{Fallopia species growth and competition abilities}

The success of invasive plants of the Fallopia genus is known for its fast growth and high regeneration abilities. All Japanese Knotweed s.l. taxa spread usually by rhizome fragments, but they are also able to regenerate from stems. New shoots can regenerate from rhizome segments which are $1 \mathrm{~cm}$ in length and $0.7 \mathrm{~g}$ fresh in weight (Brock et al. 1995). The largest of below ground biomass of Fallopia japonica has been counted to be $14,00 \mathrm{~kg}$ per hectare to a depth of $25 \mathrm{~cm}$ (Brock 1994).

Bradley et al. (2010) pointed out that fast growth and heights fecundity might allow invasive species to speedy colonize free niches. According to Beerling et al. (1994) Fallopia japonica shoots growth up to $4.3 \mathrm{~cm}$ per day. In the case of Fallopia sachalinensis, in early summer the vigorous growth reach up to $15 \mathrm{~cm}$ per day (Sukopp \& Starfinger 1995).

Fallopia taxa invasion considerably exclude native species diversity due to its competitive abilities (Bímová et al. 2004). However, field experiments have established that no single mechanism is responsible for plant species reduction (Bailey et al. 2008). Shoots of the Fallopia species are always dense and cover almost all of the invading area. Seedlings are unable to be established in the Fallopia stands (Siemens \& Blossey 2007). Shoots of the Fallopia species causes a shade and inhibits the growth of juvenile plants. They are only a few species (Urtica dioica, Ficaria bulbifera, Geranium robertianum or Aegopodium podagraria) which are co-occurring with the Fallopia genus (Bímová et al. 2004).

One of the threats which support plants invasion and establish them in new ecosystems is allelopathy (Sharma et. al 2005). Moravcová et al. (2011) suggested that allelopathy may play a role in the impact of the Fallopia genus invasion on species diversity of invaded communities, mainly due to inhibition effect on the seed germination. It was also confirmed the inhibitory effect of extract from Japanese Knotweed rhizomes (Vichotová \& Šerá 2008).

\section{Evolution by the hybridization}

Hybridization plays an important role in the invasion process of the alien plants. It is a rapid mechanism for increasing genetic variation and provides the natural selection (Lee 2002). Numerous studies have shown the examples of plant adaptability through hybridization (Lee 2002), such as adaptation to new habitats or altered environmental conditions due to climate change (Pyšek et al. 2003). Furthermore, new hybrids tend to have greater fitness, size, stronger competition abilities and increased aggression (Lee 2002).

In invasive range Fallopia species spread mainly by vegetative way, but they also show sexual reproduction by hybridization. Till now in Europe only a single genotype of Fallopia japonica, with male-sterile flowers has been found (Bailey 2003; Mandàk et al. 2005; Tiébré et al. 2007). Nevertheless, Fallopia japonica can produce seeds, because it is fertilized by the pollen of its congeners (mainly Fallopia sachalinensis) and resulting in the hybrid Fallopia $\times$ bohemica (Bailey 2003). This process can bring hybrids of the Fallopia genus which are better suited to non-native regions (Bailey 2003; Bailey et al. 2007) - what is confirmed by the results of Bimová et al. 2001 and Pyšek et al. 2003. According to the authors, Fallopia $\times$ bohemica in comparison to parents, is ecologically better adapted to human influenced environments due to its higher regenerative ability. It also possesses higher than parental species ability to spread (Mandák et al. 2004) and a greater resistance to control treatment (Bímová et al. 2001). Moreover, the hybrid can backcross with congeners and crosses between hybrids are also possible (Bailey et al. 2008). Mandák et al. (2005) pointed out that the Fallopia $\times$ bohemica attributes such as regeneration rate or shoots mass were influenced by its genotype. The genotypes with the highest 
regeneration abilities were more spread in Czech Republic than those that regenerated poorly. Genetic studies of the Fallopia genus have shown that Fallopia $\times$ bohemica is an excellent example of a species that evolves outside the native range of its parents and has adapted to local conditions by hybridization (Mandák et al. 2005). Today Fallopia $\times$ bohemica is considered as the most troublesome species of the Fallopia genus. Bímová et al. (2004) have shown that the hybrid even competes with the parental taxa at the areas where both taxa co-occur.

\section{Conclusions}

Invasive plants are a tremendously variable group, possessing various attributes conferring invasiveness. The rapid spreading of the Fallopia genus has animated the interest of its biology and ecology. Today from the knowledge of Japanese Knotweed we can conclude that wide ecological amplitude and habitat preference, a vigorous clonally growth, high competition abilities and a potential of sexual reproduction by hybridization are properties which facilitate the Fallopia genus invasion and explain its phenomena. Mentioning characteristics are observed among the most successful invaders.

\section{References}

Adachi N., Terashima I. \& Takahashi M., 1996, Central die-back of monoclonal stands of Reynoutria japonica in an early stage of primary succession on Mount Fuji, Annals of Botany 77: 477-486.

Bailey J. P. \& Stace C. A., 1992, Chromosome number, morphology, pairing and DNA values of species and hybrids in the genus Fallopia (Polygonaceae), Plant Systematics and Evolution 180: 29-52.

Bailey J. P. \& Conolly A. P., 2000, Prize-winners to pariahs - A history of Japanese Knotweed s.l. (Polygonaceae) in the British Isles, Watsonia 23: 93-110.

Bailey J. P., 2001, Fallopia $\times$ conollyana the Railway-yard Knotweed, Watsonia 23: 539-541.

Bailey J. P., 2003, Japanese Knotweeds s.l. at home and abroad, [in:] L. Child, J. H. Brock, G. Brundu, K. Prach, P. Pyšek, P. M. Wade, M. Williamson (eds.), Plant Invasions: Ecological Threats and Management Solutions, Backhuys Publishers, Leiden: 183-196.

Bailey J. P. \& Wisskirchen R., 2006, The distribution and origin of Fallopia $\times$ bohemica in Europe, Nordic Journal of Botany 24: 173-200.

Bailey J. P., Bimová K. \& Mandák B., 2007, The potential role of polyploidy and hybridization in the further evolution of the highly invasive Fallopia taxa in Europe, Ecological Research 22: 920-928.
Bailey J. P., Bimová K. \& Mandák B., 2008, Asexual spread versus sexual reproduction and evolution in Japanese Knotweed s.l. sets the stage of 'Battle of the Clones', Biological Invasions 11: 1189-1203.

Barney J. N., Tharayil N., Di Tommaso A. \& Bhowmik P. C., 2006, The biology of invasive alien plants in Canada. 5. Polygonum cuspidatum Sieb. \& Zucc. [=Fallopia japonica (Houtt.) Ronse Decr.], Canadian Journal of Plant Science 86: 887-905.

Beerling D. J., 1993, The impact of temperature on the northern distribution limits of the introduced species Fallopia japonica and Impatiens glandulifera in NorthWest Europe, Journal of Biogeography 20: 45-53.

Beerling D. J., Bailey J. P. \& Conolly A. P., 1994, Fallopia japonica (Houtt.) Ronse Decraene (Reynoutria japonica Houtt.; Polygonum cuspidatum Sieb. Zucc.), Journal of Ecology 82: 959-979.

Bimová K., Mandák B. \& Pyšek P., 2001, Experimental control of Reynoutria congeners: a comparative study of a hybrid and its parents, [in:] G. Brundu, J. Brock, I. Camarda, L. Child, M. Wade (eds.), Plant Invasions: Species Ecology and Ecosystem Management, Backhuys Publisher, Leiden: 283-290.

Bimová K., Mandák B. \& Kasparova I., 2004, How does Reynoutria invasion fit the various theories of invisibility?, Journal of Vegetation Science 15: 495-504.

Bradley B. A., Blumenthal D. M., Wilcove D. S. \& Ziska L. H., 2010, Predicting plant invasions in an era of global change, Trends in Ecology and Evolution 25: 310-318.

Brock J. H., 1994, Technical note: standing crop of Fallopia japonica in the autumn of 1991 in the United Kingdom, Preslia 66: 337-343.

Brock J. H., Child L. E., Waal L. C. \& Wade M., 1995, The invasive nature of Fallopia japonica is enhanced by vegetative regeneration from stem tissues, [in:] P. Pyšek, K. Prach, M. Rejmánek, M. Wade (eds.), Plant Invasion: General Aspect and Special Problems, Academic Publishing, Amsterdam: 131-139.

Kubota K., Nishizono H., Shiyuo S. \& Ishii F, 1988, A cooper - binding proteins in root cytoplasm of $\mathrm{Po}$ lygonum cuspidatum growing in a metalliferous habitat, Plant Cell Physiology 29: 1029-1033.

Lee C. E., 2002, Evolutionary genetics of invasive species, Trends in Ecology and Evolution 17: 386-391.

Mandák B., Pyšek P. \& Bimová K., 2004, History of the invasion and distribution of Reynoutria taxa in the Czech Republic: a hybrid spreading faster than its parents, Preslia 76: 15-64.

Mandák B., Bimová K., Pyšek P., Štěpánek J. \& Plačková I., 2005, Isoenzyme diversity in Reynoutria (Polygonaceae) taxa: escape from sterility by hybridization, Plant Systematics and Evolution 253: 219-230. 
McKinney M., 2006, Urbanization as a major cause of biotic homogenization, Biological Conservation 127: 247-260.

Mirek Z., Piękoś-Mirkowa H., Zając A. \& Zając M., 2002, Flowering plants and pteridophytes of Poland. A checklist, W. Szafer Institute of Botany, Polish Academy of Sciences, Kraków.

Moravcová L., Pyšek P., Jarošik V. \& Zákravský P., 2011, Potential phytotoxic and shading effects of invasive Fallopia (Polygonaceae) taxa on the germination of native dominant species, Neobiota 9: 31-47.

Nishizono H., Kubota K., Suzuki S. \& Ishii F., 1989, Accumulation of heavy metals in cell walls of Polygonum cuspidatum roots from metalliferous habitats, Plant and Cell Physiology 30: 595-598.

Pimentel D., Pimentel M. \& Wilson A., 2007, Plant, animal and microbe invasive species in the United States and world, [in:] W. Nentwig (ed.), Biological Invasions, Ecological Studies, Springer, Berlin: 315-330.

Pyšek P., Brock J. H., Bímová K., Mandák B., Jarošík V., Koukolíková I., Pergl J. \& Štěpánek J., 2003, Vegetative regeneration in invasive Reynoutria (Polygonaceae) taxa: the determinant of invisibility at the genotype level, American Journal of Botany 90: 1487-1495.

Richards C. H. L., Walls R. L., Bailey J. P., Parameswaran R., George T. \& Pigliucci M., 2008, Plasticity in salt tolerance traits allows for invasion of novel habitat by Japanese Knotweed s.1. (Fallopia japonica and F. $\times$ bohemica, Polygonaceae), American Journal of Botany 95: 931-942.

Rejmánek M., 1995, What makes a species invasive?, [in:] P. Pyšek, K. Prach, M. Rejmánek, M. Wade (eds.), Plant Invasions: General Aspects and Special Problems, SPB Academic Publishing, Amsterdam: 3-13.

Seiger L. A., 1997, The status of Fallopia japonica (Reynoutria japonica; Polygonum cuspidatum) in North America, [in:] J. H. Brock, M. Wade, P. Pyšek, D. Green (eds.), Plant Invasions: Studies from North America and Europe, Backhuys Publishers, Leiden: 95-102.

Sharma G. P., Singh J. S. \& Raghubanshi A. S., 2005, Plant invasion: emerging trends and future implications, Current Science 88: 726-734.

Siemens T. \& Blossey B., 2007, Anevaluation of mechanisms preventing growth and survival of two native species in invasive Bohemian Knotweed (Fallopia $\times$ bohemica, Polygonaceae), American Journal of Botany 94: 776-783.

Sukopp H. \& Starfinger U., 1995, Reynoutria sachalinensis in Europe and in the Far East: a comparison of the species ecology in its native and adventive distribution range, [in:] P. Pyšek, K. Prach, M. Reymánek, M. Wade (eds.), Plant Invasion: General Aspects and Special Problems, Academic Publishing, Amsterdam: 151-159.

Sołtysiak J., Berchová-Bímová K., Vach M. \& Brej T., 2011, Heavy metals content in the Fallopia genus in central European Cities - study from Wroclaw and Prague, Acta Botanica Silesiaca 7: 20-218.

Tiébré M.-S., Bizoux J.-P., Hardy O. J., Bailey J. P. \& Maht G., 2007, Hybridization and morphogenetic variation in the invasive alien Fallopia (Polygonaceae) complex in Belgium, American Journal of Botany 94: 1900-1910.

Tokarska-Guzik B., 2003, The expansion of some alien plant species (neophytes) in Poland, [in:] L. E. Child, J. H. Brock, G. Brundu, K. Prach, P. Pyšek, P. M. Wade, M. Williamson (eds.), Plant Invasions: Ecological Threats and Management Solutions, Backhuys Publishers, Leiden: 147-167.

Tokarska-Guzik B., 2005, The establishment and spread of alien plant species (kenophytes) in the flora of Poland, Wydawnictwo Uniwersytetu Śląskiego, Katowice.

Vichotová N. \& Šerá B., 2008, Allopathic properties of knotweed rhizome extracts, Plant Soil and Environment 54: 301-303.

Vilá M., Corbin J. D., Dukes J. S., Pino J. \& Stanley S. D., 2007, Linking plant invasion to global environmental change, [in:] J. G. Canadell, D. E. Pataki, F. L. Pitelka (eds.), Terrestial Ecosystems in a Changing World, Springer, Berlin, Heidelberg 8: 93-102.

Vitousek P. M., D’antonio C. M., Loope L. L., Rejmánek M. \& Westbrooks R., 1997, Introduced species: a significant component of human-caused global change, New Zealand Journal of Ecology 21: 1-16.

Yamaguchi F., Nozue M., Yasuda H. \& Kubo H., 2000, Effects of temperature on the pattern of anthocyanin accumulation in seedlings of Polygonum cuspidatum, Journal of Plant Research 113: 71-77.

Zika P. F. \& Jacobson A. L., 2003, An overlooked hybrid Japanese knotweed (Polygonum cuspidatum $\times s a-$ chalinense; Polygonaceae) in North America, Rhodora 105: 143-152. 
